\title{
Projecting the Learning Attainment of Speech and Hearing Impairment Students from Domestic, Discrete, Communication and Educational Aspects
}

\author{
K. Karthigadevi1,,${ }^{*} \mathrm{~S}$. Thangarasu ${ }^{2}$ \\ ${ }^{1}$ Department of Computer Applications, Kalasalingam Academy of Research and Education, Krishnankoil-626 126 \\ ${ }^{2}$ Department of Physics, Kalasalingam Academy of Research and Education, Krishnankoil-626 126
}

${ }^{1}$ k.karthikrish@gmail.com

${ }^{2}$ sthangarasu@gmail.com
*Corresponding Author

Department of Computer Applications, Kalasalingam Academy of Research and Education, Krishnankoil626126. k.karthikrish@gmail.com

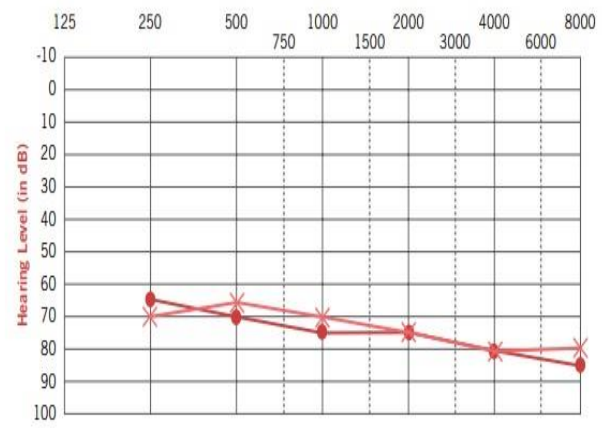

Fig.1 Audiogram representation of hearing loss in both ears
Keywords: Speech and Hearing Impaired, Linguistics, Sign language, Assistive technology, E - Learning

\section{Introduction}

Hearing impairment means loss of 60 decibels or more in the better ear in the conversational range of frequencies. Decibel is the unit of sound used to measure the level of hearing. Disability certificate is provided only for the people who have more than 60 percent of hearing loss in both the ears. Hence the hearing thresholds are fixed above $60 \mathrm{db}$. Hearing impaired person typically has an intense damage of hearing (more than $90 \mathrm{~dB}$ ).

Audiogram means graphical representation of the hearing test. Figure 1 represents the hearing loss in both ears. In the graph, $\mathrm{X}$ axis is associated with frequency or the area which is measured in Hertz $(\mathrm{Hz})$ and $\mathrm{Y}$ axis with intensity or volume which is measured in decibels $(\mathrm{dB})$. The hearing in right ear is represented by red line and the left ear by pink line.
Table I: TEN Common Myths on Speech and Hearing Impairment

\begin{tabular}{|c|c|c|}
\hline S. & MYTH & REALITY \\
No & & \\
\hline
\end{tabular}




\begin{tabular}{|c|c|c|}
\hline 1. & $\begin{array}{l}\text { The hearing loss of a } \\
\text { child can be } \\
\text { recognized after } \\
\text { completing their age }\end{array}$ & $\begin{array}{l}\text { Even in the newborn } \\
\text { babies, hearing loss can be } \\
\text { identified. }\end{array}$ \\
\hline & is three. & \\
\hline 2. & $\begin{array}{l}\text { The child will outgrow } \\
\text { hearing loss. }\end{array}$ & $\begin{array}{l}\text { The injury in the inside ear } \\
\text { will lead to enduring } \\
\text { hearing loss which cannot } \\
\text { be outgrown. }\end{array}$ \\
\hline 3. & $\begin{array}{l}\text { When the child has } \\
\text { knowledge to handle } \\
\text { the hearing aids, then } \\
\text { the hearing aids should } \\
\text { be fitted. }\end{array}$ & $\begin{array}{l}\text { Once the hearing loss is } \\
\text { identified, hearing aids } \\
\text { can be fitted, and language } \\
\text { intervention can be } \\
\text { started. }\end{array}$ \\
\hline 4. & $\begin{array}{l}\text { A child with hearing } \\
\text { loss should be } \\
\text { educated in a special } \\
\text { school. }\end{array}$ & $\begin{array}{l}\text { Many children with } \\
\text { speech and hearing } \\
\text { impairment are } \\
\text { successfully studying in } \\
\text { mainstream schools. }\end{array}$ \\
\hline 5. & $\begin{array}{l}\text { All the speech and } \\
\text { hearing-impaired } \\
\text { children are a } \\
\text { homogenous group; } \\
\text { all of them face the } \\
\text { similar problems in } \\
\text { educational aspects. }\end{array}$ & $\begin{array}{l}\text { Hearing loss differs from } \\
\text { person to person. No two } \\
\text { people have the same } \\
\text { hearing loss. }\end{array}$ \\
\hline 6. & $\begin{array}{l}\text { By using a hearing aid, } \\
\text { speech and hearing } \\
\text { impairment can be } \\
\text { 'cured'. }\end{array}$ & $\begin{array}{l}\text { It is not a 'disease' to be } \\
\text { cured. }\end{array}$ \\
\hline 7. & $\begin{array}{l}\text { While talking to a } \\
\text { child with speech and } \\
\text { hearing impairment } \\
\text { the teachers should } \\
\text { speak loudly. }\end{array}$ & $\begin{array}{l}\text { No need to speak loud to } \\
\text { the childern who are all } \\
\text { using the devices such as a } \\
\text { cochlear implant or } \\
\text { hearing aid. It may cause } \\
\text { severe pain in the child's } \\
\text { ear. }\end{array}$ \\
\hline 8. & $\begin{array}{l}\text { The cognitive abilities } \\
\text { of children with } \\
\text { speech and hearing } \\
\text { impairment are 'less'. }\end{array}$ & $\begin{array}{l}\text { Compared to normal } \\
\text { students many of the } \\
\text { speech and } \\
\text { hearingimpaired students } \\
\text { produced their effort well. }\end{array}$ \\
\hline 9. & $\begin{array}{l}\text { Maximum of the } \\
\text { people delebrate that } \\
\text { sign language is the } \\
\text { only communication } \\
\text { modem for the speech } \\
\text { and hearing-impaired } \\
\text { persons. }\end{array}$ & $\begin{array}{l}\text { Not all people who have } \\
\text { hard of hearing- or speech } \\
\text { and hearing-impaired use } \\
\text { Sign language to } \\
\text { communicate. }\end{array}$ \\
\hline 10. & $\begin{array}{l}\text { Maximum of the } \\
\text { speech and } \\
\text { hearingimpaired } \\
\text { students cannot }\end{array}$ & $\begin{array}{l}\text { Many speech and } \\
\text { hearingimpaired children } \\
\text { successfully achieved their } \\
\text { academic performance. }\end{array}$ \\
\hline
\end{tabular}

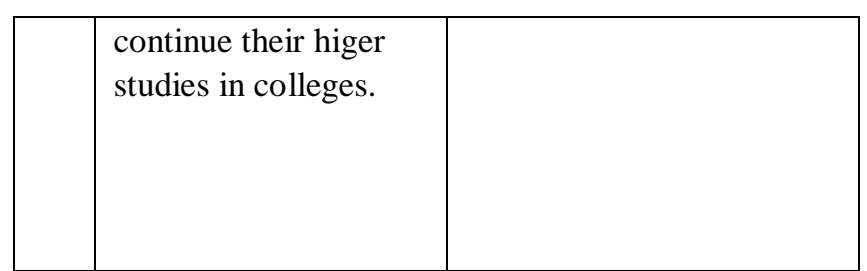

\section{Literature Review}

Allen et al. [1] examined the usage of a cochlear implant, what was the age to fix the cochlear implant, sign language usage in the home and parents hearing status. The results show that Classroom communication was significantly related to all the characteristics of the speech and hearing-impaired students. Once cochlear implantation was fixed to the speech and hearing-impaired students, they improve their speech level as well as the concentration level in the classroom. Here also they discussed all age group of speech and hearing-impaired students in implantation status, the usage of sign language in the home and reducing the probability of speech. Here the authors also provided the suggestions for future research in the field of deaf education.

Borgna et al. [2] projected four main experiments to detect the speech and hearing-impaired students. The results designated that all the speech and hearing-impaired students had thought to misjudge their performance, and also, they judge the hearing students learned more and they had a more accurate knowledge than speech and hearingimpaired students. Here the author checked the precision of metacognitive judgments for both hearing and speech and hearing-impaired students. But the result was effective only for hearing students. Speech and hearing-impaired students learned a lot from signed instruction from hearing students.

Anita et al. [3] examined the students' classroom contribution, students approachable and sensitive communication, parental contribution and communication mode in school were noticeably, but practically, related to academic results. The authors' ratings provided that $89 \%$ of speech and hearing-impaired students made average or aboveaverage progress.

Lang et al. [4] and Morere et al. [13] examined the study of social, cultural changes and the education of speech and hearing-impaired students. Here the speech and hearingimpaired people's attitudes and how they learned through the sign language were epitomized. The recent efforts of researchers examine the attitudes about hearing-impaired people, have lingered, for instance, enhancing the new systems over time.

Markschark et al. [5] proposed a possible clarification is that speech and hearing impaired and hard of hearing children do not have full access to the language and environmental diversity of their hearing peers. This condition belonging not only language development but also social functioning, mental development and knowledge of the world all of which impact each other collectively over time.

Qi, S., \& Mitchell [6] examined Perceptions on social aspects and academics of hearing-impaired children's school experiences were found and their parents. Possible 
changes between the views of hearing children and their parents compared to hearing-impaired children and their parents were of particular interest. Generally, parents of hearing impaired brought their children with higher secondary school friendship ratings than the children gave themselves, and hearing children and their parents were more positive about children's friendships than were hearing impaired children and their parents.

Shaver et al. [7] and waters et al. [12] analyzed from consultations of parent interviews and surveys exposed from parents of speech and hearing-impaired children revealed that who studied special schools especially for hearing impaired schools had a greater level of hearing loss, and they highly liked to use sign language, they have low practical knowledge and had trouble to speaking with hearing people than the hearing impaired students who had studied with regular (hearing) schools. They have no variations in the disabilities or cochlear implants between students. In several ways, the Speech and hearing-impaired students' characteristics did not vary by the schools whether it may be the regular school or special school type. The author proposed that both schools help hearing impaired students with a wide range of desires and skills.

Spencer et al. [8] inspects the research of the academic performance among speech and hearing impaired and hard of hearing students. Here the academic issues analyzed and help to reduce the problems with instructional methods and interventional methods. The more experimental research work indicated that when the experienced faculty members handled or taught the speech and hearing-impaired students may gain more knowledge. The results show that $50 \%$ of the speech and hearingimpaired students' achievement may be varied because of the instructional factors [9].

Valdes et al. [10] and knoors et al. [16] examined the result of getting transition planning education for speech and hearing-impaired students. Here the transition plan specified the postsecondary places and also indicated that the level of postsecondary students with disabilities. The author introduced the propensity model that indicated the speech and hearing-impaired students significantly increased their knowledge and they got supports from educational institutions.

Van et al. [11] and Dye et al. [15] suggested two different possibilities to describe and designate many of the main instrumental aspects, and existing significant proofbased observes that have the possibility to improve the education, communication and quality of life of speech and hearing impaired or hard of hearing and have additional severe disabilities. In this article, also examined the autism, deaf-blind and intellectual disabilities individuals. Here also identified many factors of their disabilities can be varied that is genetic syndromes, issues that happen after birth or before or during birth, otherwise traumatic brain injury such as meningitis infections were acquired later in their life.

\section{Problem Statement}

Visualizing or video learning is one of the best key aspects to teach speech and hearing-impaired students to communicate their special educational requirements. Information and Communication Technology (ICT) tools play a vital role in offering educational learning material especially for speech and hearing-impaired students. The recent learning methods using digital, as well as non-digital learning methods, differed from memorizing and degree of abstraction. So, to attain the learning objectives, change the usage of digital materials instead of regular learning (nondigital) materials. Speech and hearing-impaired students face many problems of selecting certain forms of presenting information such as graphics, images, texts and diagrams. Our research is to improve efficiency and to give recommendations for the impact of students and teachers' factors on goal attainment outcomes are analyzed.

\section{A. PURPOSE AND OBJECTIVES OF THE STUDY}

The main objective of this research work is to produce an effective teaching and learning methodology for speech and hearing-impaired students by analyzing the type of questioners as digital manners. Our research presentation affects the memorization, emotional evaluation, perception and how it contributes to the growth of various mental models.

\section{Factors for Classification of Speech and Hearing Impairment}

The cause of hearing loss is the obstacles in the auditory pathways. Some specific terms associated with various types of hearing loss can be stated in reports or in the individual education plans of children. Analyzing the terms and the various types of hearing loss will be useful to device instructional strategies. As shown in Table1, there are five elements to consider in the classification of speech and hearing impairment: degree, site of lesion/injury, age of onset, causal factors and nature.

Table II: Five Factors for classification of speech and hearing impairment

\begin{tabular}{|l|l|l|l|}
\hline $\begin{array}{l}\text { S. } \\
\text { No }\end{array}$ & Factors & Explanation & Classification \\
\hline 1. & Degree & $\begin{array}{l}\text { Hearing loss } \\
\text { may be } \\
\text { different even } \\
\text { in both ears } \\
\text { and it can } \\
\text { never be the } \\
\text { same. }\end{array}$ & $\begin{array}{l}\text { Depending upon the } \\
\text { levels of dB audible } \\
\text { to a child, hearing } \\
\text { loss can be classified } \\
\text { as Mild, moderate, } \\
\text { moderately severe, } \\
\text { severe and Profound. }\end{array}$ \\
\hline 2. & $\begin{array}{l}\text { Site of } \\
\text { lesion/ } \\
\text { injury }\end{array}$ & $\begin{array}{l}\text { Hearing loss } \\
\text { might be } \\
\text { caused due to } \\
\text { any injury or } \\
\text { harm to } \\
\text { various parts } \\
\text { of the ear. }\end{array}$ & $\begin{array}{l}\text { Depending upon the } \\
\text { site of injury i.e. the } \\
\text { lesion, hearing loss is } \\
\text { classified as } \\
\text { Sensorineural, } \\
\text { conductive, mixed }\end{array}$ \\
\hline
\end{tabular}




\begin{tabular}{|l|l|l|l|}
\hline | & & & $\begin{array}{l}\text { and central auditory } \\
\text { functioning. }\end{array}$ \\
\hline 3. & $\begin{array}{l}\text { Age of } \\
\text { onset }\end{array}$ & $\begin{array}{l}\text { Hearing loss } \\
\text { could be } \\
\text { developed at } \\
\text { any time } \\
\text { during the } \\
\text { lifespan. }\end{array}$ & $\begin{array}{l}\text { Depending upon the } \\
\text { age of onset, hearing } \\
\text { loss is further } \\
\text { classified as, } \\
\text { acquired, congenital, } \\
\text { pre-lingual and } \\
\text { Postlingual. }\end{array}$ \\
\hline 4. & $\begin{array}{l}\text { Causal } \\
\text { factors }\end{array}$ & $\begin{array}{l}\text { Hearing loss } \\
\text { can be caused } \\
\text { because of } \\
\text { various } \\
\text { reasons. }\end{array}$ & $\begin{array}{l}\text { Some of the particular } \\
\text { causes leading to } \\
\text { hearing loss can be } \\
\text { classified as noise, } \\
\text { post-natal and pre- } \\
\text { natal. }\end{array}$ \\
\hline 5. & Nature & $\begin{array}{l}\text { Hearing loss } \\
\text { never occurs } \\
\text { in a similar } \\
\text { manner. }\end{array}$ & $\begin{array}{l}\text { Depending upon the } \\
\text { nature, hearing loss } \\
\text { can be classified as } \\
\text { sudden and gradual }\end{array}$ \\
\hline
\end{tabular}

\section{Methodology}

The research study involved qualitative, experimental and quantitative research methods: Interviews, questionnaires, discussions and tests. The persistence of this experimental work is to evaluate the qualitative and quantitative characteristics of speech and hearing-impaired students depending on the perception such as pattern recognition, attention, information processing, decision making, logical thinking, memorizing, etc. The effective teaching methodology for speech and hearingimpaired students involves the levels of development of its carriers such as computer screen, tablet, interactive whiteboard, papers and smartphones.

The following methodological assessment and evaluation are used:

i. The research experiments involving the analysis of awareness and attention of speech and hearingimpaired students

ii. The research experiments involving the analysis of memory

iii. The research experiments involving the process of logical thinking, information and reading comprehension, verbal skills, reading ability. iv. The research experiments involving mental models

\section{Result and Discussions}

The sample involved of 40 speech and hearing-impaired students and 20 normal students from the Kalasalingam Academy of Research and Education. The average age for the sample student was 20 years. The tests have been grouped under the headings of intellectual capacity, closure, association, non - verbal short-term memory, and verbal short-term memory.

Table III: Comparison Result for Speech and Hearing Impaired and Normal Students

\begin{tabular}{|c|c|c|c|}
\hline $\begin{array}{l}\text { S. } \\
\text { No }\end{array}$ & Methods & $\begin{array}{l}\text { Speech and } \\
\text { HearingImpaired } \\
\text { students }\end{array}$ & $\begin{array}{l}\text { Normal } \\
\text { Students }\end{array}$ \\
\hline \multirow[t]{2}{*}{1.} & \multicolumn{3}{|c|}{ Intellectual capacity } \\
\hline & $\begin{array}{l}\text { Systematic } \\
\text { Reasoning }\end{array}$ & $78 \%$ & $87 \%$ \\
\hline \multirow[t]{3}{*}{2.} & \multicolumn{3}{|l|}{ Closure } \\
\hline & Objects & $75 \%$ & $80 \%$ \\
\hline & Morphology & $93 \%$ & $97 \%$ \\
\hline \multirow[t]{4}{*}{3.} & \multicolumn{3}{|l|}{ Association } \\
\hline & Categorization & $87 \%$ & $83 \%$ \\
\hline & Analogies & $92 \%$ & $94 \%$ \\
\hline & $\begin{array}{l}\text { Spatial } \\
\text { relationships }\end{array}$ & $93 \%$ & $89 \%$ \\
\hline \multirow[t]{4}{*}{4.} & \multicolumn{3}{|c|}{ Nonverbal short-term memory } \\
\hline & Designs & $99 \%$ & $98 \%$ \\
\hline & Movement & $68 \%$ & $75 \%$ \\
\hline & Sequences & $58 \%$ & $65 \%$ \\
\hline \multirow[t]{4}{*}{5.} & \multicolumn{3}{|c|}{ Verbal short-term memory } \\
\hline & Letters & $80 \%$ & $91 \%$ \\
\hline & Words & $75 \%$ & $74 \%$ \\
\hline & Sentences & $55 \%$ & $66 \%$ \\
\hline
\end{tabular}

The results indicate that the performance of speech and hearing-impaired students obtains short-term memory. Most of the speech and hearing-impaired students that are more than $60 \%$ hearing loss is easier to remember the words which are displayed on the digital board. The speech and hearing-impaired students remembered an average of 7 words out of 10 words from the electronic board and a regular printout they memorized 6 words. The speech and hearingimpaired students remembered one word more from the digital board compared to a printout.

According to the results of experiments, speech and hearing-impaired students who got a lower percentage of loss managed with the task easily and answered all the questions. But the speech and hearing-impaired students who got above $60 \%$ of loss did not manage with the task with difficulty to answer the questions. In other words, reading and understanding of the text of 230 - 250 words in a time limited to 2-3 minutes is a serious challenge for them. In general, $60 \%$ of students with speech and hearing impairment did not cope with the task at all, other works contained significant errors, 
and only $12 \%$ of the works testified partly correct understanding of the text.

The results of the first stage of our experiment allow us to draw some conclusions about the information perception by speech and hearing-impaired students from paper and electronic media, as well as to give some recommendations on their use. Memorization speed and short-term memory are among the most important factors ensuring successful learning. A significant difference between the speech and hearing-impaired students and hearing students is observed in the perception of textual information. As part of the proposed assignment, students had to read a small artistic text, understand it, remember the general meaning and details in a limited time interval, and then answer questions about it. For students with speech and hearing impairments, this has proven to be an impossible task. Thus, according to the results of this experiment when organizing training for deaf and speech and hearingimpaired students, the following recommendations can be given:

impaired students showed both "worst" and "best" results. After analyzing the results and interviewing students, the following explanation was formulated: in most cases, the perception of information is influenced mostly not by the degree of deafness, but by the factors that contribute to the mental development of the child, including the child's mental characteristics, the cause of deafness and the resources provided by his environment. Deafness acts as a limiting factor of selfcognition and self-knowing of the world, but if there are factors in the child's environment that help overcome this limitation, they contribute to his development considerably.

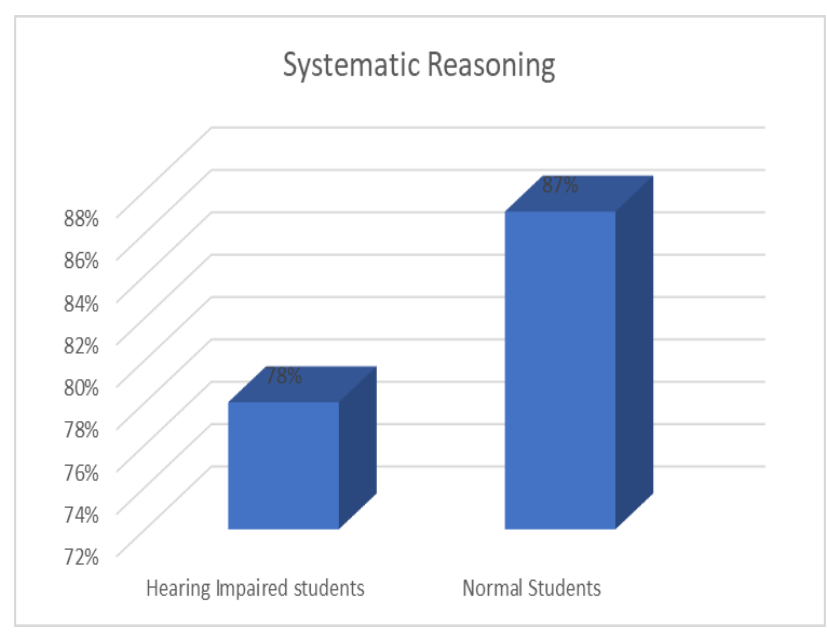

Fig. 2 Intellectual Capacity

The above fig. 2 represents the average test results in intellectual capacity of both speech and hearing impaired as well as normal students.
- The development of methodological support should take into account the peculiarities of perception of information, in particular, it is better to use different sources of information, both electronic and paper, during the lesson

- It is not effective to offer theoretical material on slides in the form of textual information, the information should be as simple as possible and presented using images, symbols, tables, charts, etc.

- Material for memorization such as formulas, terms and rules will be expedient to put on the slides and demonstrated on the electronic board

- Tasks requiring concentration and attention such as instructions and search problems are advisable to offer as printed material on paper

On the one hand, in general, the speech and hearingimpaired students are usually less successful in their studies but our experiments have shown that this relation is not direct, as completely speech and hearing-

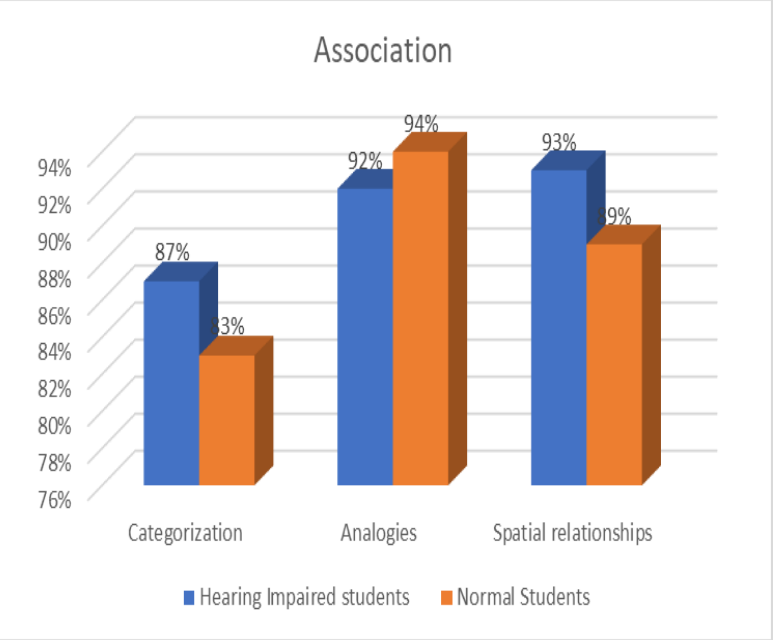

Fig. 4 Association

The above fig. 4 represents the average test results in association of both speech and hearing impaired as well as normal students.

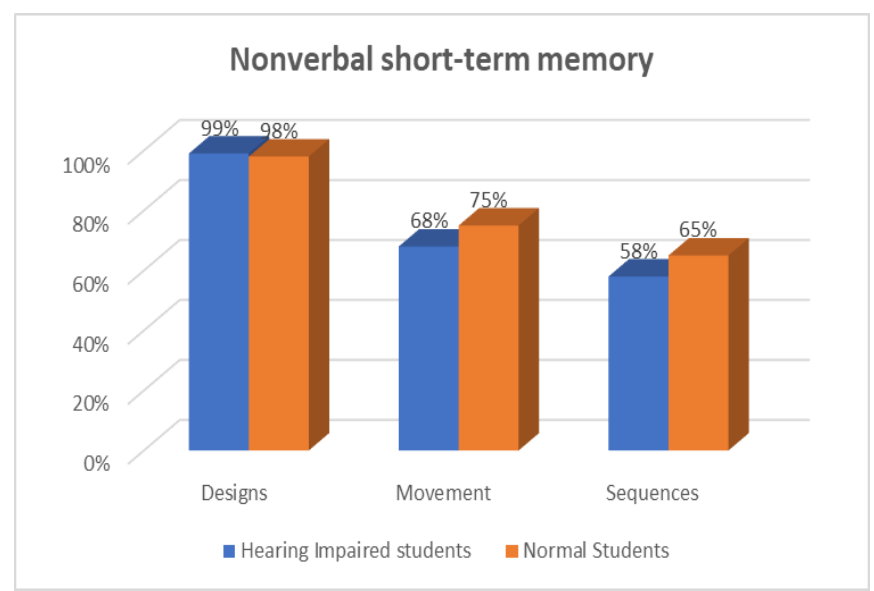




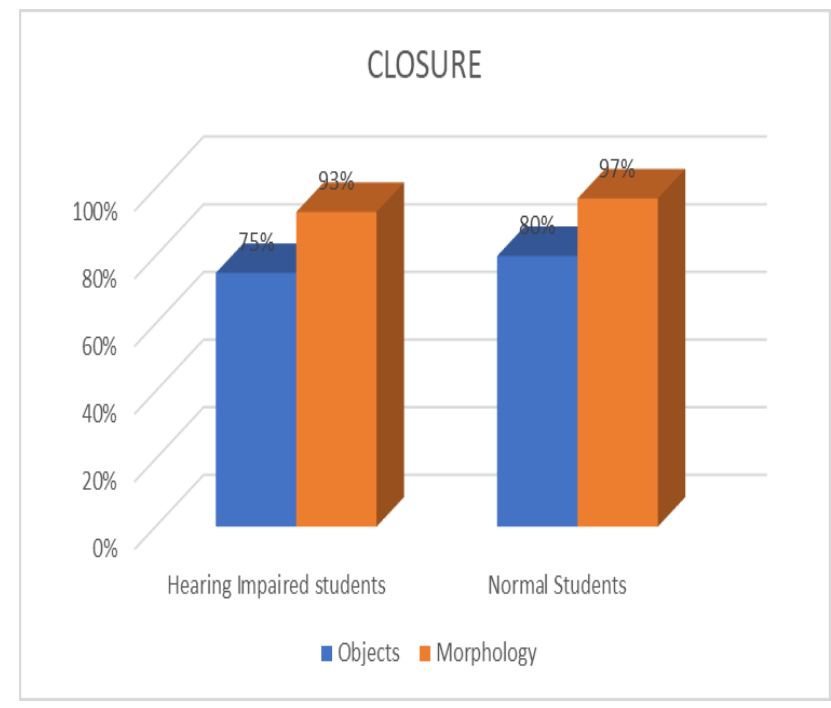

Fig. 5 Nonverbal short-term memory

The above fig. 5 represents the average test results in nonverbal short-term memory of both speech and hearing impaired as well as normal students.

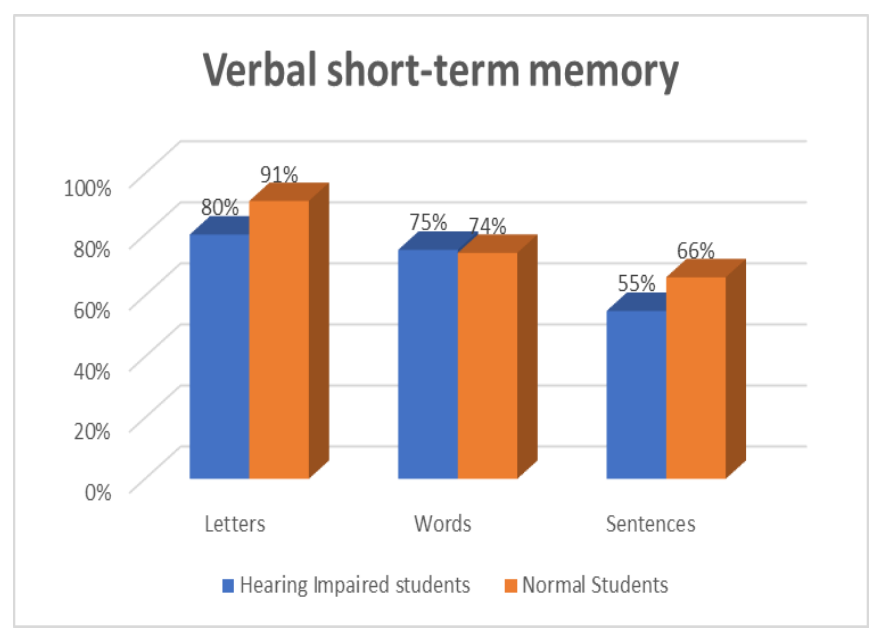

Fig. 3 Closure

The above fig. 3 represents the average test results in closure capacity of both speech and hearing impaired as well as normal students.

Fig. 6 Verbal short-term memory

The above fig. 6 represents the average test results in verbal short-term memory of both speech and hearing impaired as well as normal students.

\section{Conclusion}

We conclude that one of the greatest challenges is the training of teachers who are able to deal with speech and hearing-impaired students and students with a health standard in one classroom. While in the system of special education for speech and hearing-impaired school children, teachers, as a rule, undergo special training aimed at developing skills for special needs education, the university teachers are not prepared to respond equally to the educational needs of speech and hearing-impaired students studying together with hearing students.

The study showed that the speech and hearing-impaired students are eager to continue their higher education. Particularly if they are provided with the right tools, the majority of these students are keen on studying higher education. The results show that the impact of a student (i.e., disability status) on goal attainment outcomes were analyzed.

\section{Reference}

[1] Allen, T. E., \& Anderson, M. L. (2010). Deaf students and their classroom communication: An evaluation of higher order categorical inter-actions among school and background char-acteristics. Journal of Deaf Studies and Deaf Education, 15, 334-347. doi:10.1093/deafed/enq034

[2] Borgna, G., Convertino, C., Marschark, M., Morrison, C., \& Rizzolo, K. (2011). Enhancing deaf students' learning from sign language and text: Metacognition, modality, and the effec-tiveness of content scaffolding. Journal of Deaf Studies and Deaf Education, 16, 79100. doi:10.1093/deafed/enq036 
[3] Antia, S., Jones, P., Reed, S., \& Kreimeyer, K. (2009). Academic status and progress of deaf and hard-ofhearing students in general educa-tion classrooms.

Journal of Deaf Studies and Deaf Education, 14, 293311. doi:10.1093/deafed/enp009

[4] Lang, H. (2011). Perspectives on the history of deaf education. In M. Marschark \& . Spencer (Eds.), The Oxford handbook of deaf studies, language, and education(Vol. 1, 2nd ed., pp. 7-17). New York, NY: Oxford University Press. doi:10.1093/oxfordhb/9780199750986.013.0002

[5] Marschark, M., Bull, R., Sapere, P., Nordmann, E., Skene, W., Lukomski, J., \& Lumsden, S. (2012). Do you see what I see? School per-spectives of deaf children, hearing children, and their parents. European Journal of Special Needs Education, 14, 483-497. doi:10.1080/08856257.2012.719106

[6] Qi, S., \& Mitchell, R. E. (2012). Large-scaled academic achievement testing of deaf and hard-of-hearing students: Past, present, and future. Journal of Deaf Studies and Deaf Education, 17, 1-18. doi:10.1093/deafed/enr028

[7] Shaver, D., Marschark, M., Newman, L., \& Marder, C. (2014). Who is where? haracteristics of deaf and hardofhearing students in regu-lar and special schools. Journal of Deaf Studies and Deaf Education, 19, 203219. doi:10.1093/deafed/ent056

[8] Spencer, P. E., \& Marschark, M. (2010). Achievement in mathematics and Science. In P. E. Spencer \& M. Marschark, Evidence-based practice in educating deaf and hard-of-hearing students (pp. 135-152). New York, NY: Oxford University Press.

[9] U.S. Government Accountability Office. (2011). Deaf and hard of hearing children: Federal support for developing language and literacy. Retrieved from http://www.gao.gov/new.items/d11357.pdf

[10] Valdes, K., Godard, P., Williamson, C., Van Campen, J., McCracken, M., Jones, R., \& Cameto, R. (2013). National Longitudinal Transition Study-2 (NLTS2) Waves 1, 2, 3, 4, and 5 data documentation and dictionary. Menlo Park, CA: SRI International.

[11] Van Dijk, R., Nelson, C., Postma, A., \& van Dijk, J. (2010). Assessment and intervention of deaf children with multiple disabilities. In M. Marschark \& P. Spencer (Eds.), The Oxford handbook of deaf studies, language, and education(Vol. 2, pp. 172-191). New York, NY: Oxford University Press.
[12] Wauters, L. N., van Bon, W. H. J., Tellings, A. E. J. M., \& Van Leeuwe, J. (2006). In search of factors in deaf and hearing children's reading comprehension. American Annals of the Deaf, 151, 371-380. doi:10.1353/aad.2006.0041

[13] Morere, D. (2013a). Measures of reading achieve-ment. In D. Morere \& T. Allen (Eds.), Assessing literacy of deaf individuals(pp. 107-126). New York, NY: Springer. doi:10.1007/978-1-4614-5269-0_6

[14] U.S. Government Accountability Office. (2011). Deaf and hard of hearing children: Federal support for developing language and liter-acy. Retrieved from http://www.gao.gov/new.items/d11357.pdf

[15]Dye, P., Hauser, P., \& Bavelier, D. (2008). Visual attention in deaf children and adults:Implications for learning environments. In M. Marschark \& P. Hauser (Eds.), Deaf cog-nition(pp. 250-263). New York, NY: Oxford University Press.

[16] Knoors, H., \& Marschark, M. (2014). Teaching deaf learners: Psychological and develop-mental foundations. New York, NY: Oxford University Press 